\title{
Effects of Ground-Based Skidding on Forest Soil
}

\author{
Ahmad Solgi* \\ Department of Forestry, University of Guilan, Iran
}

Submission: May 08, 2018; Published: June 21, 2018

"Corresponding author: Ahmad Solgi, Department of Forestry, Faculty of Natural Resources, University of Guilan, P0.Box 1144, Sowmeh Sara, Guilan, Iran, Tel: +98-1344323599; Fax: +98-1344323600; Email: aforestsolgi@gmail.com; solgi_ahmad231@yahoo.com

\section{Introduction}

Ground-based logging systems are used for extracting timber from the forest for delivery to a roadside landing. For many years, animals were the primary power for logging operations in the world [1]. Logging was carried out by men and animals long before the introduction of the modern skidders, mechanized wheel loaders, and tractor-trailers [2]. The deployment of machinery in timber harvesting and skidding has the potential to cause detrimental soil and site disturbances due to the size, power and weight of the machinery $[3,4]$. Site disturbance may result in degradation of soil properties, which is evidenced by increased soil compaction, decreased soil porosity and infiltration, and increased surface runoff and erosion that may cause an overall decline in site productivity [5]. Soil compaction is perceived as one of the leading causes of forest soil disturbance resulting from mechanized forest operations. Machine-induced soil compaction strongly reduces soil porosity and pore connectivity, and increases soil density and shear strength [6]. When dry bulk density increases, a reduction in total soil porosity, tree height, diameter, and volume growth will often be observed. Decreases in porosity through the elimination of macropores and the reduction of soil infiltration capacity as well as the rate of water movement into the soil are associated with compaction from timber harvesting [5].

A large number of factors influence the extent and severity of soil compaction. These factors can be generally divided in two main groups: machine parameters and operating characteristics (axle load, traction type, traffic frequency, etc.) $[7,8]$ as well as climate, site, and soil characteristics [5,9].

\section{Traffic Frequency}

The number of machine passes is a factor that significantly influences the degree of soil damage [10]. Machine passes have an important influence on soil structural characteristics, soil aeration and the soil water balance, and may therefore considerably affect soil organisms and root development. The initial passes cause the highest increase in soil compaction in relation to subsequent passes but these may lead to further soil disturbance by deepening the ruts.
Slope

During skidding on the steep terrain, a given load gets uneven weight balance on the axles (usually rear axle) and increases soil disturbance. Najafi et al. [11] found that, during timber harvesting, terrain slope had a stronger effect on soil disturbance so that snig track related disturbance was greater on slopes $>20 \%$ than on slopes $<20 \%$. The increase of bulk density in the steeper trail slope may be associated with a reduced speed of the skidder. When a skidder passes more slowly because of slope steepness, the top soil is vibrated more and consequently becomes more compacted compared to trails on more gentle slopes. Furthermore, when logs are pulled on steep slope trails, usually the rear axle receives a higher load and induces more pressure on the soil. Uneven load distribution can cause slipping on steep slopes due to a reduced rear wheel radius. More pressure, slipping, and lower speed may have been responsible for a dramatically increased soil disturbance seen on the steep slope trail [11]. Finally, the tendency of the skidder toward the downhill combined with a greater force of the load toward the downhill side of the skidder would also explain increased disturbances on the steep slope trail.

\section{Soil Moisture Content}

The soil moisture content during logging can significantly influence the degree of soil disturbance, with greater potential for more soil compaction on wet/saturated soils than on dry soils [5,9]. This occurs because as the soil becomes wetter, the water film weakens the interparticle bonds and reduces internal friction by lubricating the particles, which allows soil particles to slide together and compact by squeezing out air. However, the bulk density can decrease again at higher soil water contents after the maximum density has been reached, because with the further addition of water, soil has greater pore water pressures and becomes less compactable [12].

\section{Soil Texture}

Soil bulk density is strongly influenced by soil texture because this property has a major effect on the average pore size and mechanical resistance of a compacted soil. Rab et al. [13] 
reported that soil texture is one of the most important factors, which determines the susceptibility of a soil to compaction. Coarse-textured soils are less susceptible to compaction than those with a fine texture [14]. Moreover, Taylor et al. [15] found considerable differences in soil strength depending on soil texture. A soil with a large fraction of fine particles (silt and clay) will have smaller pore diameters and a higher penetration resistance at a lower bulk density than a soil with a large fraction of coarse particles.

\section{Skidding Direction}

Finally, the direction of machine traffic (i.e. uphill vs. downhill) can modify the impact of vehicle traffic on the soil. Solgi et al. [16] concluded that the direction of skidding had an effect on soil compaction. Differences in levels of compaction between uphill and downhill skidding may be explained by an uneven load distribution between the downhill and uphill tires of the skidder or increased wheel slippage and vibration in uphill compared to downhill skidding [16].

\section{Logging Methods}

Increased levels of compaction of the forest soil and disruption of the soil environment are the unavoidable consequences, however. Nonetheless, some types of machinery used in timber harvesting can significantly reduce the extent of soil disturbance. Naghdi et al. [8] showed that the crawler skidder can cause smaller increases in bulk density than rubbertired skidders, even though the weight of the crawler skidder was 1 t higher than that of the Timber jack $45^{\circ} \mathrm{C}$. However the ground pressure of the crawler skidder was lower than that of the Timber jack $45^{\circ} \mathrm{C}$ and it has been documented that tyres with a higher contact area can reduce soil compaction [17] and that steel-tracked skidders may have a lower impact on the soil than rubber-tired skidders due to lower static ground pressures [18]. In general, tracks are better able to limit soil compaction than wheels. For rubber-tired skidders, low ground pressure exerted on the soil by wide tyres may be a way to produce less topsoil compaction [19].

\section{Ground Pressure}

The average static ground pressure on a rigid surface, which under common conditions is related to the tire inflation pressure, can significantly influence the degree of soil compaction. Arvidsson \& Keller [20] found that tire inflation pressure has a large influence on soil stresses measured at a depth of $10 \mathrm{~cm}$ below the soil surface. Solgi et al. [21] determined that topsoil compaction depends directly on ground pressure. By increasing ground pressure, the soil disturbance was more severe [21]. Reduced ground pressure exerted by wide (flotation) tires operated on soils produces a lower increase in soil density [17].

\section{Curve Angle}

In mountainous areas, ground transport in steep terrain is often performed on roads or skid trails that consist of narrow and single lanes with frequent switchback curves [22]. In curves, wheeled skidders are subjected to physical forces that cause load transfer, which is a change of the load borne by different wheels that transfers more weight and ground pressure from the inner to the outer wheels (i.e., wheels closest to the outer edge of the curve) [23]. Applying a greater mechanical force on the soil should thus lead to enhanced soil compaction in curves, and more so in narrow curves and on curves that traverse steep terrain. Solgi [24] demonstrate that as few as three passes of harvesting equipment over the same area of skid trail were sufficient to push soil conditions in the apex (i.e., central plot) close to critical threshold values that have been shown to be detrimental to future plant growth and long-term site productivity.

\section{References}

1. Shrestha SP, Lanford BL, Rummer R, Dubois M (2008) Soil disturbances from horse/mule logging operations coupled with machines in the southern United States. Int J For Eng 19(1): 17-23.

2. Creighton J (1997) Logging trucks, tractors and crawlers. Osceola (WI): Motorbooks International, USA, pp. 128.Ampoorter E, Goris R, Cornelis WM, Verheyen K (2007) Impact of mechanized logging on compaction status of sandy forest soils. For Ecol Manage 24(1-3): 162-174.

3. Kozlowski TT (1999) Soil compaction and growth of woody plants. Scand J For Res 14(6): 596-619.

4. Naghdi R, Solgi A, Ilstedt U (2016) Soil chemical and physical properties after skidding by rubber-tired skidder in Hyrcanian forest, Iran. Geoderma 265: 12-18.

5. Solgi A, Najafi A, Sadeghi SH (2014) Effects of traffic frequency and skid trail slope on surface runoff and sediment yield. International Journal of Forest Engineering 25(2): 171-178.

6. Solgi A, Naghdi R, Tsioras PA, Nikooy M (2015) Soil compaction and porosity changes caused during the operation of Timberjack $450 \mathrm{C}$ skidder in northern Iran. Croatian Journal of Forest Engineering 36: 77-85.

7. Greacen EL, Sands R (1980) Compaction of forest soils. A review Aust J Soil Res 18: 163-189.

8. Naghdi R, Solgi A, Zenner EK (2015) Soil Disturbance Caused by Different Skidding Methods in North Mountainous Forests of Iran. International Journal of Forest Engineering 26(3): 212-224.

9. Naghdi R, Solgi A (2014) Effects of skidder passes and slope on soil disturbance in two soil water contents. Croatian Journal of Forest Engineering 35 (1): 73-80.

10. Jun HG, Way TR, Löfgren B, Landström M, Bailey AC, et al. (2004) Dynamic load and inflation pressure effects on contact pressures of a forestry forwarder tire. J Terram 41(4): 209-222.

11. Najafi A, Solgi A, Sadeghi SH (2009) Soil disturbance following four wheel rubber skidder logging on the steep trail in the north mountainous forest of Iran. Soil Till Res 103(1): 165-169.

12. Mosaddeghi MR, Hajabbasi MA, Hemmat A, Afyuni M (2000) Soil compactibility as affected by soil moisture content and farmyard manure in central Iran. Soil Til Res 55(1-2): 87-97.

13. Rab A, Bradshaw J, Campell R, Murphy S (2005) Review of Factors Affecting Disturbance, Compaction and Trafficability of Soils with Particular Reference to Timber Harvesting in the Forests of South-West Western Australia, Sustainable Forest Management Series, Australia, pp. 145.

14. Naghdi R, Solgi A, Labelle ER, Nikooy M (2017) The combined effects of soil texture and machine operating trail gradient on changes in soil physical properties during ground-based skidding. Pedosphere. 
15. Taylor HM, Robertson GM, Parker JJ (1966) Soil strength-root penetration relations for medium to coarse-textured soil materials. Soil Sci. 102(1): 18-22.

16. Solgi A, Naghdi R, Tsioras PA, Ilstedt U, Nikooy M, et al. (2017) Combined effects of skidding direction, skid trail slope and traffic frequency on soil disturbance in north mountainous forest of Iran. Croatian Journal of Forest Engineering 38: 97-106.

17. Botta GF, Becerra AT, Tourn FB (2009) Effect of the number of tractor passes on soil rut depth and compaction in two tillage regimes. Soil Till Res 103(2): 381-386.

18. Sheridan GJ (2003) A comparison of rubber-tyred and steel-tracked skidders on forest soil physical properties. Aus J Soil Res 41(6): 10631075 .

19. Victor C, Cartwright A (1993) Benefits of low pressure tyres in agriculture. World Agric 2: 151-154.
20. Arvidsson J, Keller T (2007) Soil stress as affected by wheel load and tyre inflation pressure. Soil Till Res 96(1-2): 284-291.

21. Solgi A, Naghdi R, Labelle ER, Tsioras PA, Nikooy M (2016) Effect of varying machine ground pressure and traffic frequency on the physical properties of clay loam soils located in mountainous forests. International Journal of Forest Engineering 27(3).

22. Cavalli R, Grigolato S (2010) Influence of characteristics and extension of a forest road network on the supply cost of forest woodchips. J For Res 15(3): 202-209.

23. Pacejka HB (2012) Tire and vehicle dynamics, ( $3^{\text {rd }}$ edn), ButterworthHeinemann, Oxford, UK, pp. 632.

24. Solgi A (2016) Evaluation of forest soil disturbance in relation to some effective parameters on skid trail designing. Ph.D Thesis. University of Guilan, Iran pp. 130

\section{Your next submission with Juniper Publishers will reach you the below assets} DOI: 10.19080/JOJHA.2018.01.555571
- Quality Editorial service

- Swift Peer Review

- Reprints availability

- E-prints Service

- Manuscript Podcast for convenient understanding

- Global attainment for your research

- Manuscript accessibility in different formats

( Pdf, E-pub, Full Text, Audio)

- Unceasing customer service

Track the below URL for one-step submission https://juniperpublishers.com/online-submission.php 